\title{
Edaphic and Microclimate Factors Affecting Tobosagrass Regrowth after Fire
}

\author{
LEON F. NEUENSCHWANDER AND HENRY A. WRIGHT
}

\begin{abstract}
The plant-air layer and soil surface structure affect regrowth succession following burning in the tobosagrass (Hilaria mutica)mesquite (Prosopis glandulosa) community in West Texas by altering the microenvironment. Data are presented for the plant-air layer and the soil surface structure as they are related to the recovery of the tobosagrass and the successional response of the annuals. Changes in plant-air layer and the soil surface structure alter the microenvironment and affect plant growth and species composition. A conceptual model is developed illustrating vegetational development as affected by the plant-air layer and the soil surface structure.
\end{abstract}

In the last decade, many research papers have been written about the response of tóbosagrass (Hilaria miutica) following burning. The tobosagrass-mesquite (Prosopis glandulosa) community in the southern-mixed prairie of West Texas is a simple community dominated largely by tobosagrass. The literature on tobosagrass, reviewed by Neuenschwander et al. (1975), indicates that production, forage quality, and utilization are increased by removing excessive litter. Spring burning is the most inexpensive method of removing the litter tobosagrass. At the same time, fire top kills and, under proper fire weather conditions, inflicts mortality on mesquite. Tobosagrass and mesquite populations following spring burns have been studied for as long as 6 years (Wright 1972, 1974; Wright et al. 1976). The community structure and vegetational development have been reported by Neuenschwander et al. (1978), while the effect of burning on the soils of that area has been studied by Whigham (1976), Sharrow and Wright (1977), and Ueckert et al. (1978).

Data from these studies and additional data on microclimate and surface soil structure will be used to formulate a conceptual model for vegetational development and to demonstrate that the plant-air layer and the surface soil structure affect the vegetational development following fire in the tobosagrass-mesquite community.

The primary objective of this report is to demonstrate the importance of the microenvironment created by the plant-air layer and soil surface plates on the regrowth of tobosagrass and on the succession of annuals. The secondary objective is to provide data from previous studies in the tobosagrass-mesquite communities to support a unifying theory on the regrowth and vegetational development in the mesquite-tobosagrass community.

Attempts to frame a single theory of succession have identified some intriguing properties of communities, but no universal pattern or unifying theory has been developed (Horn 1974, 1975, 1976; Connell and Slatyer 1977). Keever (1950) studied causes of succession and found that life cycle strategies of pioneer plants are very important. If soil remains unaltered (Coile 1940), light (Oosting

\footnotetext{
Authors are associate professor of forest resources, University of Idaho, Moscow 83843 and Horn professor of range and wildlife management, Texas Tech University, Lubbock 79409.

This research is a contribution of the College of Agricultural Sciences, Texas Tech University, and the University of Idaho, Forestry, Wildlife and Range Experiment Station, Contribution Number 229.

The authors wish to thank Drs. C.T. Gaskins, T. E.A. Van Hylekama, S.C. Bunting. R.E. Sosebee, B. Dahl, C. Rowell, N. West, G. Spomer, R.J. Vogl, and M. Hironaka
} for their generous expenditures of time in reviewing this manuscript. and Kramer 1946) and soil water relations (Crafton and Wells 1934, Olson 1958) are important. Since tobosagrass resprouts from rhizomes following fire, critical factors for plant growth and development are also important. In reviews of successionai patterns, Drury and Nisbet $(1971,1973)$ point out that much of the empirical evidence for successional patterns of biomass and organic development of the soil is inferred. With the possible exception of Olson's (1958) sand dune paper, basic data directed to determine successional mechanisms following fire have not been reported.

\section{Methods}

This study was conducted on the southwestern edge of the Rolling Plains on the Spade Ranch, $22.5 \mathrm{~km}$ south of Colorado City, Mitchell County, Texas. The area is transitional between the humid climate of central Texas and semiarid climate of the western region of Texas (Soutiere 1971). The macroclimate averages 50.3 $\mathrm{cm}$ precipitation per year with a high daily maximum average summer temperature of $36^{\circ} \mathrm{C}$ during July. Winds are predominantly from the southwest. The average annual potential evaporation is about $254 \mathrm{~cm}$. High evaporation and transpiration rates in conjunction with runoff during heavy summer thunderstorms provide a more xeric condition than the average precipitation might indicate.

Study areas were restricted to the Stamford soil series. The Stamford series consists of nearly level to gently sloping areas ( 1 to $3 \%$ slopes) of deep and well-drained calcareous clays. Both Stamford and Dalby clays were present in undifferentiated units (Stoner et al. 1969). Except for one control, study areas were aerially sprayed with 2,4,5-trichlorophynoxyacetic acid (2,4,5-T) in 1966. The herbaceous vegetation had recovered from the herbicide by 1969 (Neuenschwander 1976). Beginning in 1969, 220 hectares (500 acres) to 1,012 hectares $(2,500$ acres) were burned each year through 1975. Techniques and conditions of the burns in the sprayed tobosagrass community were given by Britton and Wright (1971).

The entire area was lightly grazed year long (about 2 cows/ha), with a four-pasture deferred rotation system. Based on small enclosures in tobosagrasslands, grazing was insignificant and removed less than $15 \%$ of the unburned forage (Heirman and Wright 1973, Wright 1972). In this study, burned plots were protected from grazing because cattle concentrated in recently burned areas and consumed up to $85 \%$ of the yield in recently burned areas (Wright 1972).

Seven treatments were selected for this study. The first 6 were sprayed with 2,4,5-T in 1966. Five of these sprayed treatments were then burned at intervals providing a sequence of 1-, 2-, 3-, 4- and 6-year-old burns, respectively. Treatment 6 constituted a spray, but not burned treatment, and treatment 7 served as an untreated control. Twenty-five quadrats $\left(25 \times 25 \mathrm{~cm}^{2}\right)$ were located in each of 2 homogenous tobosagrass stands (minimium $25 \times 25 \mathrm{~m}^{2}$ ) within each of the 7 treatments.

On these treatment areas, Ueckert et al. (1978) studied the effect of burning on infiltration and Sharrow and Wright studied nitro- 
gen dynamics (1977).

Soil surface plates (soil crust) are polygonal plates that form in the Stamford soil. The thickness of these surface plates was measured. Fifty samples were collected in each treatment from between the canopies of tobosagrass on 3 dates. Surface plates were also measured between and within the root crown of tobosagrass in each treatment.

Soil temperature was measured on 7 dates with thermometers placed between canopies of tobosagrass on the freshly burned and the sprayed control. On 3 of these dates, 20 thermometers were placed between and within the canopies of tobosagrass.

Soil moisture was measured with a calibrated relative soil moisture meter (Edmund Sci. Co. No. 80, 159). Soil moisture was measured on resistance scale from 1 to 12 scale and converted to a percent soil moisture by gravimetric calibration. Fifty samples were used in a curvilinear regression of the relative scale to percent soil moisture and to test the reliability of the instrument. This method was selected because of the rapidity in which samples could be collected in the field on the Stamford clay soils.

Three replications of 25 soil moisture samples were taken at a 5-to 10-cm depth between the canopies of tobosagrass in the treatments during the June and July season. Samples were collected 2 to 3 days after a 2.5 - to $5.0-\mathrm{cm}$ rain with the soil in a drying phase. This procedure was selected to reduce variation and isolate treatment differences. Samples were collected in 2 consecutive years, 1974 and 1975.

Duplicate samples for the analysis of percent organic carbon were taken at a $0-$ to $2.5 \mathrm{~cm}$ depth and replicated 6 times on the different aged burns and the sprayed control. Percent organic carbon was obtained through the Walkley and Black (1934) method.

Bacteria colonies were counted in 1974 and 1975. Data were taken by standard plating and culturing techniques and replicated 6 times on different age burns and the control (Frobisher 1968). Samples were randomly collected from the surface plates at a 0 - to 2.5-cm depth. Samples were taken in the unburned plot and burned plots of the first, third, and fifth growing seasons after the burn.

Data were analyzed using a completely random design, and the difference between means was determined by Duncan's multiple range test (Cochran and Cox 1957). Both a paired $t$-test and grouped $t$-test were used for the appropriate data. Sample sizes were adequate to detect differences at the $5 \%$ level of significance.

\section{Results and Discussion}

In vegetational development where climax species recover following fire, factors affecting successional processes must include resprouting, plant reestablishment, and factors affecting vegetational regrowth. The most important factors are water, air, and soil around individual plants. We examined soil temperature, soil moisture, soil surface structure, soil organic carbon, surface litter, and canopy cover. Biomass (Neuenschwander et al. 1978), soil nitrogen data (Sharrow and Wright 1977), and soil water relationships (Ueckert et al. 1978) were extracted from previous studies. Based on biomass, the burned tobosagrass community reaches equilibrium with the control within 6 years after the fire (Neuenschwander et al. 1978).

The plant-air layer is the microenvironment created by the canopy structure of the plant. Because of the growth form of tobosagrass, the plant-air layer includes the current year's growth, litter in the canopy, and litter on the soil surface (Fig. 1). Total plant cover, as defined here, is composed of litter held in the canopy, litter on the soil surface, and the current year's growth of tobosagrass. Thus, cover is a quantitative expression of the plant-air layer. Burning reduced the canopy cover of tobosagrass from $74.0 \%$ before the fire to $0 \%$ immediately after the fire. By the middle of the first growing season, the canopy cover of tobosagrass was restored to $16.3 \%$. Canopy cover increased $Y=0.7+\log _{10} X$ after burning (Fig. 2); where $\mathrm{Y}$ is the percent canopy cover and $\mathrm{X}$ is the growing

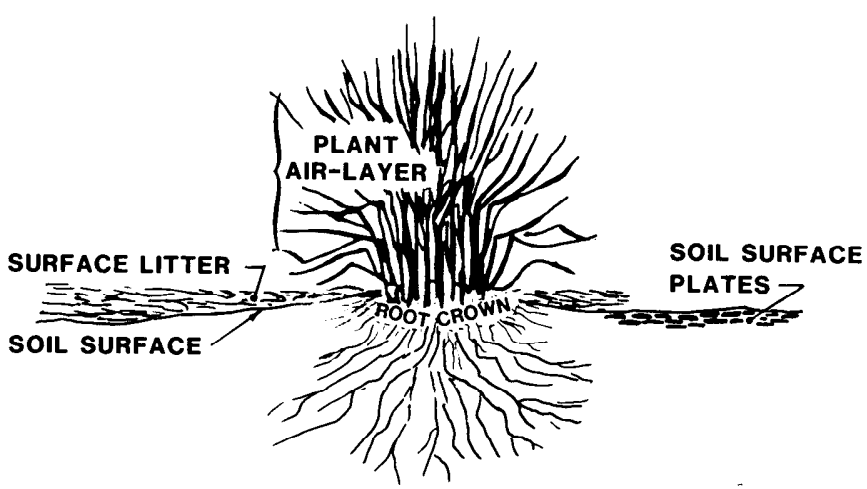

\section{TOBOSAGRASS}

Fig. 1. An illustration of the plant-air layer and soil surface plates found with tobosagrass on a Stamford clay.

season after the burn $(X \leq 6)$. Canopy cover reached equilibrium by the fifth growing season after the burn. Recovery time of canopy coverages was similar to that of biomass (Neuenschwander et al. 1978).

Fire alters soil temperature, moisture, surface structure, and organic carbon, but physical and chemical properties of the soil

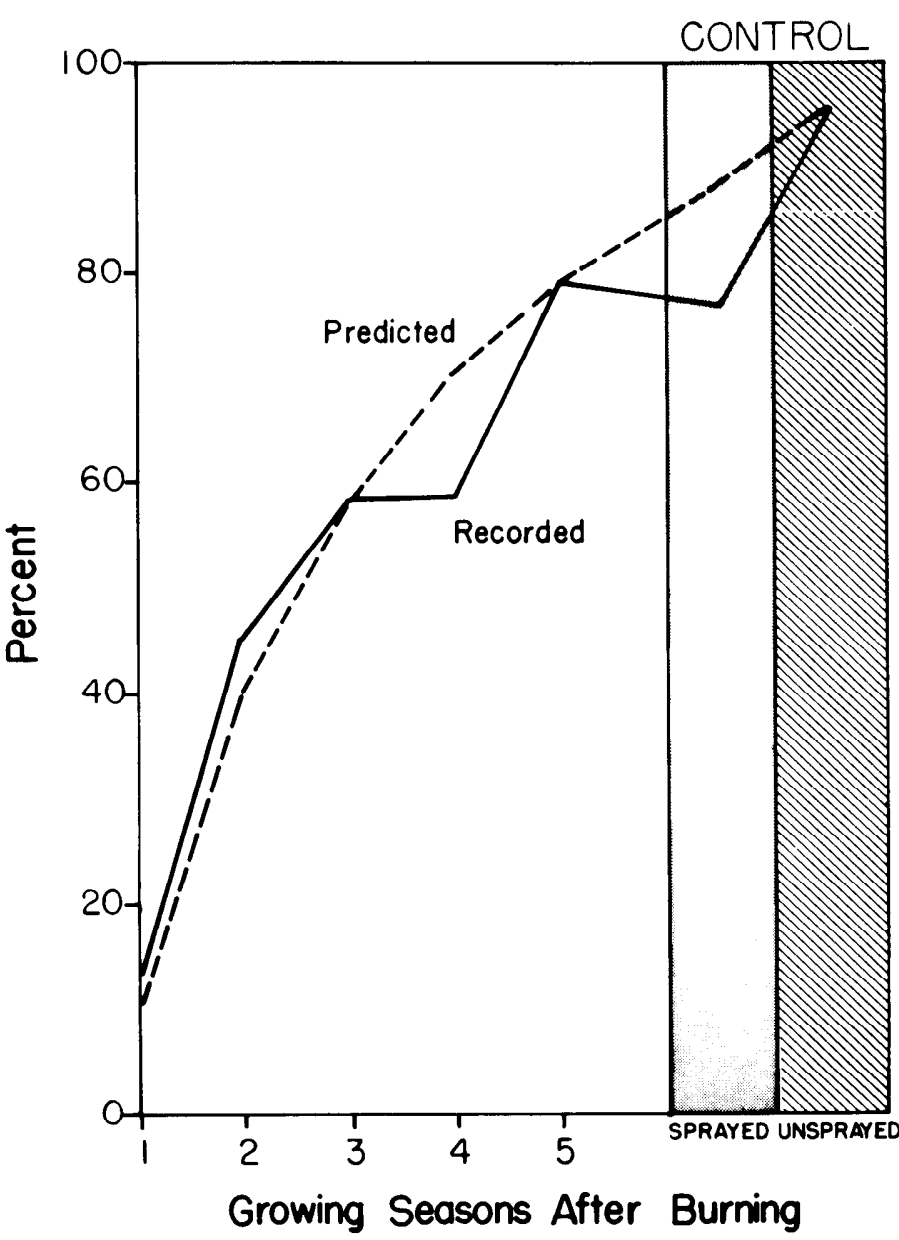

Fig. 2. Average percent grouped cover for all species for the growing seasons after the burn and for two unburned controls (the sprayed control and the unsprayed control). The dashed line was drawn from predicted points $\left(Y=0.7 \times \log _{10} X\right.$, where $X$ was the growing season after the burn). 
below $5 \mathrm{~cm}$ do not change significantly (Whigham 1976). The return of these soil properties to preburned conditions is important in the reestablishment of vegetation.

\section{Microclimate}

Sharrow (1973) found a yearly average soil temperature of $6.7^{\circ} \mathrm{C}$ higher on recently burned than on unburned plots at a $2.5 \mathrm{~cm}$ depth. Refining his technique, he sampled at a depth of $7.5 \mathrm{~cm}$ between April and July and found an average temperature difference between burned and unburned plots of $3.9^{\circ} \mathrm{C}$.

In this study, soil temperature samples were stratified based on canopy of tobosagrass. Thermometers were placed within and between the canopies of tobosagrass (Table 1). Soil surface

Table 1. Soil temperature means taken at a soil depth of $2.5 \mathrm{~cm}$ between and within canopies of tobosagrass on unburned and on one- and two-year-old bums.

\begin{tabular}{lcc}
\hline & \multicolumn{2}{c}{ Soil temperature $\left({ }^{\circ} \mathrm{C}\right)$} \\
\cline { 2 - 3 } Plots & Between canopies & Within canopies \\
\hline Unburned & $33^{\mathrm{a}_{1}}$ & $30^{\mathrm{a} * 2}$ \\
Growing season after burn & & \\
1 & $43^{\mathrm{c}}$ & $31^{\mathrm{a}_{*}}$ \\
2 & $39^{\mathrm{b}}$ & $30^{\mathrm{a}_{*}}$ \\
\hline
\end{tabular}

'Column means followed by the same letter were not significantly different $(P<0.05)$. 2* Row means were significantly different $(P<0.05)$.

temperature varied significantly between burned and unburned areas by dates, but this variation was primarily between the canopies of tobosagrass and not within the canopies. Soil temperature means were not different within the canopy and root-crown of tobosagrass throughout the sere, but they were different between the canopies. This implied that the surface temperature reached equilibrium when the canopy cover reached equilibrium, or about 5 years after the burn in the tobosagrass community.

Soil moisture was measured between the canopies (Table 2) and

Table 2. Soil moisture (\%) means taken between the root crowns for unburned and burned plots by the number of growing seasons after the burn at a soil depth of $2.5 \mathrm{~cm}^{1}$.

\begin{tabular}{lll}
\hline & \multicolumn{2}{c}{ Soil moisture (\%) } \\
\cline { 2 - 3 } Plots & 1974 & 1975 \\
\hline Unburned & $26^{\mathrm{bc}}$ & $20^{\mathrm{d}}$ \\
Growing season after burn & & \\
1 & $22^{\mathrm{a}}$ & $18^{\mathrm{a}}$ \\
2 & $24^{\mathrm{b}}$ & $15^{\mathrm{a}}$ \\
3 & $25^{\mathrm{bc}}$ & $18^{\mathrm{b}}$ \\
4 & $26^{\text {cd }}$ & $19^{\mathrm{bc}}$ \\
5 & $28^{\mathrm{d}}$ & $20^{\mathrm{bcd}}$ \\
6 & $28^{\mathrm{d}}$ & $18^{\mathrm{abc}}$ \\
\hline
\end{tabular}

Data were averages from 25 readings taken after 1.5 inches rain in 1974 and 1975 on two and three dates, respectively.

${ }^{2}$ Means in columns followed by the same letter were not significantly different $(P<0.01)$.

within the root crown of tobosagrass. A statistical difference in soil moisture was evident between the canopies of tobosagrass, but not within root crowns. This implied that surface soil moisture also reached equilibrium at the same time as biomass and canopy cover.

Soil moisture differences in the burned and unburned areas were present at different depths during the growing season. The soil surface was dry ( $7 \%$ ) between tobosagrass canopies, but not within root crowns (12\%). Between canopies of tobosagrass, soil moisture increased rapidly with depth. During the growing season, soil moisture at $2.5 \mathrm{~cm}$ was $18.0 \%$ between canopies, and it was $21.5 \%$ within the root crowns.

Sharrow (1973) studied soil moisture at $2.5 \mathrm{~cm}$ in burned and unburned tobosagrass plots. His work indicated that the unburned plots had a yearly average of $4.8 \%$ more soil moisture than the burned plots. He compared clipped to unclipped tobosagrass plots, and found that litter reduced soil water loss by $2 \%$ in the plot without active roots and about $6 \%$ in the plot with active roots. He suggested that about $2 \%$ was evaporational loss and $4 \%$ was transpirational loss.

Higher soil temperatures on burned areas created higher evaporation from the surface, but, at the same time, when sufficient soil moisture was present at root depth available moisture to the plant root system increased. When conditions were very dry, tobosagrass assumed dormancy (Herbel 1963, Nkemdirim and Haley 1973).

\section{Infiltration}

Ueckert et al. (1978) studied infiltration. Initially, differences were observed in simulated rainfall infiltration rates among the different ages of burns. However, these differences seemed to be related to site differences rather than to the effects of fire (Whigham 1976). Analyses of co-variance using bulk density, noncapillary porosity, capillary porosity, silt, sand, and antecedent soil moisture as co-variables revealed no significant differences in total 40-minute infiltration between treatments as determined by the modified Purdue sprinkling infiltrometer. Similarly, no differences in infiltration were found for any of the 5-minute intervals during the 40-minute period. However, the double-ring infiltrometer revealed significant differences in infiltration rates among treatments (Whigham 1976). Infiltration was lowest on recently burned areas and increased with lapse of time following burning. Infiltration rates on burned areas approached that of unburned areas after 3 to 5 years (Ueckert et al. 1978) (Table 3).

Table 3. Means of infiltration rates (adjusted by covariance) on control and on different age burns, modified from Whigham (1976).

\begin{tabular}{lcc}
\hline \hline & $\begin{array}{c}\text { Infiltration } \\
\text { (Purdue) } \\
\text { (in/40 min) }\end{array}$ & $\begin{array}{c}\text { Infiltration } \\
\text { (Rings) } \\
\text { (mm/hr) }\end{array}$ \\
\hline Unbuts & $2.1^{\mathrm{al}}$ & $130^{\mathrm{do}}$ \\
Growing season after burn & & \\
1 & $1.1^{\mathrm{a}}$ & $79^{\mathrm{abc}}$ \\
2 & $2.0^{\mathrm{a}}$ & $63^{\mathrm{abc}}$ \\
3 & $1.2^{\mathrm{a}}$ & $82^{\mathrm{abc}}$ \\
4 & $1.4^{\mathrm{a}}$ & $91^{\text {bed }}$ \\
6 & $2.1^{\mathrm{a}}$ & $149^{\mathrm{e}}$ \\
\hline
\end{tabular}

'Means within a column followed by the same letter are not significantly different $(R<0.10)$.

\section{Tobosagrass-Soil Interactions}

Current year's growth of tobosagrass increased about 3 times after burning in a normal rainfall year than in stands not burned for at least 4 years (Neuenschwander 1976, Sharrow 1975, Wright 1972). The yield decreased after the first growing season according to $Y=3125-604 X+24 X^{2}$ where $Y$ is the predicted yield $(\mathrm{kg} / \mathrm{ha})$ and $X$ is the growing season after the burn (Fig. 1). About $80 \%$ of the growth during the first growing season was attributed to litter removal (Sharrow 1973). Fertilization as a result of the combustion process was thought to be important (Wright 1972), but ash alone had little affect on plant growth (Sharrow 1975). However, Sharrow (1975) found available nitrogen to increase after burning (Table 4). The increase was attributed to an increase in microflora activity.

Bacterial colonies were counted for 2 successive years, 1974 and 1975 (Fig. 3). Bacterial growth increased tenfold after the burn. Populations on burned areas decreased exponentially after the first growing season until equilibrium with the unburned area was reached. This growth, when moisture was sufficient, was primarily attributed to higher soil temperatures and increased organic carbon levels following burning.

Initially, organic carbon increased by $47 \%$ at the soil surface 
between the above- and below-ground biotic functions was formed. It was relatively impervious.

Surface plates increased in thickness for 3 years on the same soil, then began to decrease (Table 5) until they reached preburn conditions by the sixth growing season.

Table 5. Soil surface plate thickness (cm) by growing season after burning was compared to unburned areas.

\begin{tabular}{lcccccc}
\hline & \multicolumn{5}{c}{ Burned } & Unburned \\
\cline { 2 - 6 } Growing seasons: & 1 & 2 & 3 & 5 & 5 & control \\
\hline Surface plate & $2.0^{\mathrm{abl}}$ & - & $2.4^{\mathrm{b}}$ & $2.1^{\mathrm{ab}}$ & $1.3^{\mathrm{a}}$ & $1.3^{\mathrm{ab}}$ \\
\hline
\end{tabular}

'Row means followed by the same letter were not statistically different $(\mathcal{P}<0.01)$.

Surface plates may cause a redistribution of soil moisture and of heat load (Fig. 5). Horizontal surface water redistribution has been reported previously by Perry (1970) and Slatyer (1961). Noy-Meir (1973) reported both horizontal and vertical water redistribution anisotropically throughout the soil profile in arid regions. Root crown areas were higher in organic matter and were shaded more by the vertical canopy than areas between plants. Also, the basal cover of tobosagrass was reduced by $12 \%$ by burning. Surface plates do not form in the burned-out root crowns; therefore, root crowns offer an entrance for water runoff that would normally be lost due to the presence of the relatively impervious surface plates. Surface runoff may be channeled into the root crowns where it enters the soil system. By virtue of root crown entrance, the following seemingly contradictory data were compatible: (1) a relatively impervious surface plate was formed, and (2) the total infiltration rate was about the same in the Purdue sprinkling method but not in the double ring method. The Purdue microplots were $.24 \mathrm{~m}^{2}$, and there were many tobosagrass plants within each plot. However, the double ring areas were small $\left(.10 \mathrm{~m}^{2}\right)$ and contained fewer plants within the area.

The relatively impervious surface plates also probably reduced the evaporation from the soil surface. Thus, the surface plate may have contained a part of the soil moisture allocated to evaporation and retained it within the soil system.

Probably surface plates were important in the thermal properties of the soil. The heavy clay soil expanded and contracted with wetting and drying. An air space may have occurred below the soil crust. There was a zone of separation which created an air space between the surface plates and the soil below the plates, but the thickness of the air space was not constant $(\leq 3 \mathrm{~mm})$. It fluctuated with moisture content and a great deal of natural variation existed with similar moisture conditions.

The importance of the air space was thermal insulation. When the space was saturated with moisture, the surface heat load was readily transferred into the soil due to the high heat conductivity of water. The air space under dry conditions acted as a barrier to vertical heat movement due to the insulation effect of the low heat capacity of the dry soil. During the growing season, the net result below the surface plate was warmer, moist conditions after summer rains and cooler, dry conditions during summer drought. The warmer and moister conditions, with the increased availability of organic matter, induced rapid biological decomposition of organic debris by the microflora immediately after burning.

\section{Vegetational Development}

In the tobosagrass-mesquite community, the physical factors are not severely distorted by fire. The first stage in vegetational development is bare ground immediately after the plant-air layer is removed by the fire, and the plant-air layer is thus destroyed. By the middle of the first growing season, the community is dominated by tobosagrass, which resprouts from cxtensive rhizomes and basal root crowns. Annuals are rare in the first growing season except for a legume (Hoffmannsigia glauca). After the fire, the interface between the organic horizons $\left(\mathrm{O}_{1}\right.$ and $\left.\mathrm{O}_{2}\right)$ and the mineral soil $\left(A_{1}\right)$ becomes an abrupt boundary between plant-air and soilsurface environments.

Vegetational development proceeds, at the interface on the soil surface, as the plant-air layer redevelops $\left[Y=0.7+\log _{10} \mathrm{~S}\right.$, where $Y$ is the percent canopy cover, $\mathrm{X}$ is the growing season after the burn, and $X \leq 6]$. Surface soil moisture and temperature relationships are regulated by the plant-air layer. The successional pattern of increased annuals, which are xeric species in this community, during the second, third, and fourth growing season is described by Neuenschwander et al. (1978). Annuals are confined to areas between the canopies of tobosagrass. Annuals extend their distribution from the higher dry sites into the more mesic lower sites as the soil surface plates form. Also, annuals remain for a longer time because of the presence of surface plates. Their density and diversity are correlated with the formation and development of the soil surface plate. As plates increased in thickness, diversity and density of annuals increased. As surface plates decreased, annual plant diversity and density decreased. Thus, successional patterns of annuals correspond to development of the soil surface plate. The surface plates are an expression of the interface between the soil and the plant-air layer. Suil surface plates modify the soil-surface environment in that it alters hydro-thermal properties in the clay soil.

Vegetational development proceeds as organic debris is deposited on the soil surface. Continual incorporation of organic material from the litter into the soil occurs at the interface between the plant-air/soil-surface. This boundary becomes more continuous as a result of organic matter incorporation at the interface and leaching. The plant-air layer forms the environment for the soil-litter organisms. Their successional patterns follow litter accumulation (Engelmann 1961, Blake 1925). The microfauna and flora with the mesofauna reach their maximum successional development as the plant-air layer and soil-surface reach equilibrium in their vertical structure. At the same time, soil moisture and temperature become less extreme as the microenvironment becomes more mesic and the interface boundary becomes less discrete. Producers and decomposers with corresponding trophic levels react to the changing environment. Competition favors species that are adapted to this more mesic environment. Consequently, xeric species are replaced by mesic species.

Both pre-burned and post-burned stages are dominated by tobosagrass. However, freshly burned areas are dominated by green tobosagrass and the post-burn areas, after the fifth growing season, are overshadowed by the litter of tobosagrass. The climax stand contains few other herbaceous plants and an impoverished annual flora with a diminished productivity of tobosagrass due to the buildup of litter (Neuenschwander et al. 1978).

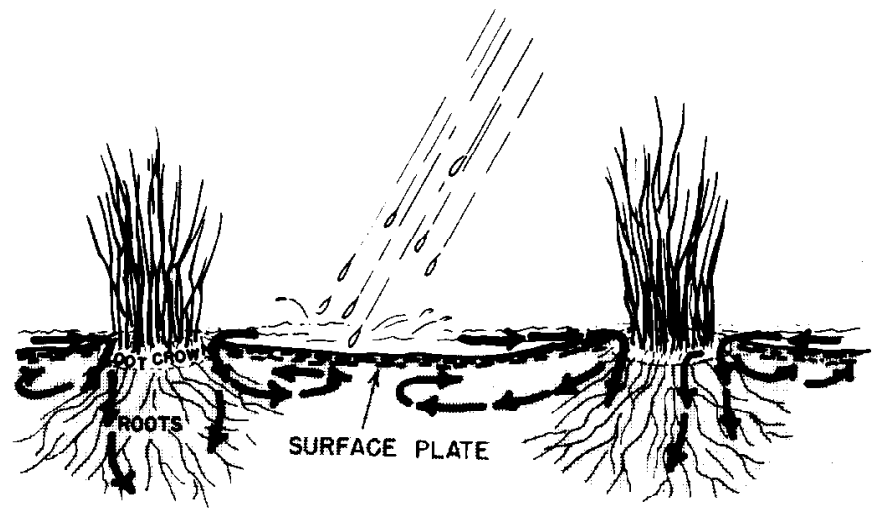

Fig. 6. The pathway of water in a burned tobosagrass community where surface plates were formed. 


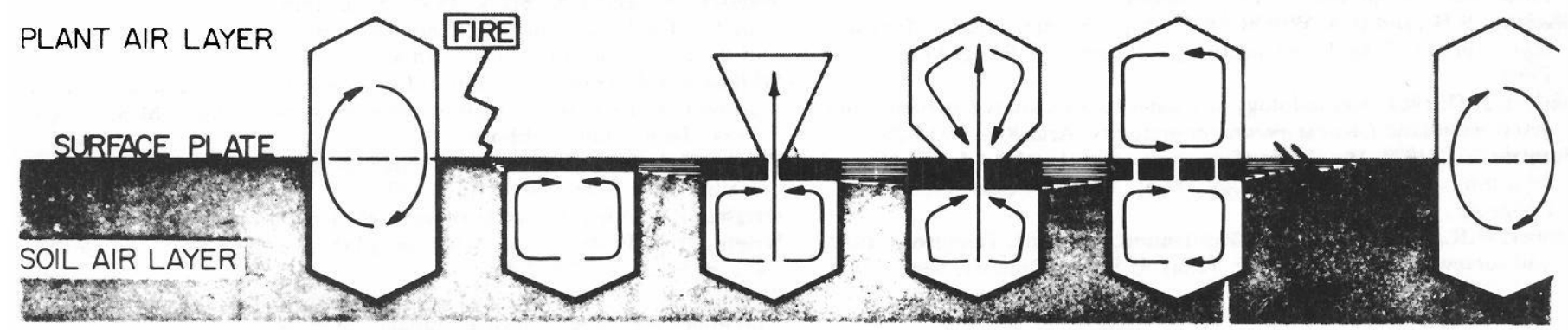

Fig. 7. Model for the plant-air/soil-surface interface hypothesis for vegetational development following burning in the tobosagrass-mesquite communities. Five seral stages, A through E, are symbolized by the polygons for the plant-air and soil-surface layers separated by the surface plate. The arrows represent transport of organic debris and minerals. State " $A$ " is the climax " $B$ " is freshly burned, and " $C$ " the burn in the

\section{The Model}

The model for plant-air layer/ soil-surface interface for regrowth and vegetational development following fire in the tobosagrassmesquite community is conceptualized by Figure 7. The arrows in the seral stages B through E indicate an interrupted or restricted flow of organic material; consequently, energy and mineral flow. In climax stand "A," "OMIS" (organic matter incorporating system) is viewed as relatively continuous within the plant-air/soilsurface environments. When environments are united through a diffuse surface plate, the interface is not well defined. The burn occurs before "B." Inflow of organic and inorganic debris probably occurs by physical rather than biological processes. The net flow of energy is upward, and the interface is abrupt. As the surface plate thickens, it restricts vertical flow of organic material. The process is restricted until the surface plate is removed and the plant-air/soilsurface environments are relatively continuous.

The plant-air and soil-surface layers are functional during all the seral stages of secondary succession. Since the climate and soil remain the same following burning in the tobosagrassland, the successional process is completed when both the plant-air and soil-surface environment have returned to the original condition. At that point, "OMIS" is relatively continuous, and the interface is not an abrupt boundary. Thus, the community is in a steady state with the climate of the area.

"OMIS" unites the plant-air layer/soil-surface. Without transport of organic debris and minerals, regrowth of tobosagrass and succession of annuals cannot proceed. It provides the mechanism for habitat modification through soil enrichment and for a more mesic environment. "OMIS" may be the driving force in vegetational development as it provides the gradient for competitive replacement of species and the energetic properties for growth and development during the seral process in the tobosagrass-mesquite community.

\section{Literature Cited}

Bertrand, A.R., and J.F. Parr. 1961. Design and operation of the Purdue sprinkling infiltrometer. Purdue Univ. Agr. Exp. Sta. Bull. No. 723.

Blake, I.H. 1925. A comparison of animal communities of coniferous and deciduous forests. Biol. Monogr. 10:371-520.

Britton, C.M., and H.A. Wright. 1971. Correlation of weather variables to mesquite damage by fire. J. Range Manage. 24:136-141.

Cochran, W.G., and G.H. Cox. 1957. Experimental design. 2nd Ed. John Wiley and Sons, Inc. New York.

Coile, T.S. 1940. Soil changes associated with loblolly pine succession on abandoned agricultural land of the Piedmont Plateau. Duke Univ. School of Forestry Bull. 5:1-85.

Connell, J.H., and R.O. Slatyer. 1977. Mechanisms of succession in natural first growing seasons. Stage "D" occurs during the second and third growing season and represents the point before litter in the canopy is returned to the soil surface. It is the seral stage of annual invasion. In state "E," the plant-air layer has been restored, but the soil-surface has not. Bio-transport is restricted by the soil surface plate.

communities and their role in community stability and organization. Amer. Natur. 111:1119-1139.

Crafton, W.M., and B.W. Wells. 1934. The old field prisere: an ecological study. Elisha Mitchell Sci. Soc. Jour. 49:225-246.

Dortignac, E.J. 1951. Design and operation of Rocky Mountain infiltrometer. U.S. Forest Serv., Rocky Mtn. Forest and Range Exp. Sta. Pap. 5.

Drury, W.H., and I.C.T. Nisbet. 1971. Inter-relations between developmental models in geomorphology, plant ecology, and animal ecology. Gen. Syst. 16:57-68.

Drury, W.H., and I.C.T. Nisbet. 1973. Succession. J. Arnold Arboretum, Harvard Univ. 54:331-368.

Engelmann, M.D. 1961. The role of soil arthropods in the energetics of an old field community. Ecol. Monogr. 31:221-238.

Frobisher, M. 1968. Fundamentals of microbiology. W.B. Saunders Co., Philadelphia.

Gardner, W.H. 1965. Water content. p. 82-127. In: Methods of soil analyses. Ed. A. Black. No. 9 Monogr. Ser. Part I. Amer. Soc. Agron.

Heirman, A.L., and H.A. Wright. 1973. Fire in medium fuels. J. Range Manage. 16:133-138.

Herbel, C.H. 1963. Fertilizing tobosa on flood plains in the semi-desert grassland. J. Range Manage. 16:133-138.

Horn, H.S. 1974. The ecology of secondary succession. Ann. Rev. Ecol. Syst. 4:25-37.

Horn, H.S. 1975. Markovian properties of forest succession. p. 196-211. In: Ecology and Evolution of Communities. Ed. Martin L. Cody and Jared M. Diamond. Harvard Univ. Press. Cambridge, Mass.

Horn, H.S. 1976. Succession. p. 187-204. In: Theoretical ecology. Ed. Robert M. May. W.B. Saunders Co., Philadelphia.

Keever, C. 1950. Causes of succession on old fields of the Piedmont, North Carolina. Ecol. Monogr. 20:229-250.

Marshall, T.J., and G.B. Stirk. 1950. The effect of lateral movement of water in soil on infiltration measurements. Aust. J. Agr. Res. 1:253-265.

Neuenschwander, L.F. 1976. The effect of fire in a sprayed tobosagrassmesquite community on Stamford clay soils. Ph.D. Diss., Texas Tech. Univ., Lubbock, Texas.

Neuenschwander, L.F., S.H. Sharrow, and H.A. Wright. 1975. Review of tobosagrass (Hilaria mutica). Southwest. Natur. 20:255-263.

Neuenschwander, L.F., S.C. Bunting, and Henry A. Wright. 1978. The effect of fire on a tobosagrass-mesquite community in the rolling plains of Texas. Southwest. Natur. 23:315-338.

Nkemdirim, L.C., and P.F. Haley. 1973. An evaluation of grassland evapotranspiration. Agr. Meteorol. 11:373-383.

Noy-Meir, I. 1973. Desert ecosystems: environment and producers. Ann. Rev. Ecol. Syst. 3:25-51.

Olson, J.S. 1958. Rates of succession and soil changes on southern Lake Michigan sand dunes. Botan. Gaz. 119:125-170.

Oosting, H.J. and P.J. Kramer, 1946. Water and light in relation to pine reproduction. Ecology 27:47-53.

Perry, R.A. 1970. The effect on grass and browse production of various treatments on a mulga community in central Australia. Proc. Int. Grassland Congr. 11:63-66. 
Sharrow, S.H. 1973. Soil nitrogen in a tobosagrass community. M.S. Thesis, Texas Tech. Univ., Lubbock.

Sharrow, S.H. 1975. Effects of fires, ash, and litter on tobosa production. Ph.D. Diss., Texas Tech. Univ., Lubbock.

Sharrow, S.H., and H.A. Wright. 1977. Proper burning intervals for tobosagrass in west Texas based on nitrogen dynamics. J. Range Manage. (In Press).

Slatyer, R.O. 1961. Methodology of a water balance study conducted on a desert woodland (Acacia aneura) community. Arid Res. 16:15-26.

Soutiere, E.C. 1971. The effects of mesquite control with 2,4,5-T and fire on mourning dove nesting ecology. M.S. Thesis, Texas Tech. Univ., Lubbock.

Stoner, H.R., T.J. Holder, D.L. McClennon, and K.M. Templeton. 1969. Soil survey of Mitchell County, Texas. U.S. Soil Conserv. Serv.
Ueckert, D.N., T.L. Whigham, and B.M. Speers. 1978. Effect of burning on infiltration, sediment, and other soil properties in a mesquite-tobosagrass community. J. Range Manage. 31:420-425.

Walkley, A., and I.A. Black. 1934. An examination of the Degtjareff method for determining soil organic matter and proposed modification of the chromic acid titration method. Soil Sci. 37:29-38.

Whigham, T.L. 1976. The effects of fire on selected physical and chemical properties of soil in a mesquite-tobosagrass community. M.S. Thesis, Texas Tech. Univ., Lubbock.

Wright, H.A. 1972. Fire as a tool to manage tobosa grasslands. Proc. Tall Timbers Fire Ecol. Conf. 12:153-167.

Wright, H.A. 1974a. Range burning. J. Range Manage. 27:5-11.

Wright, H.A. 1974b. Effect of fire on southern mixed prairie grasses. J. Range Manage. 27:417-419.

Wright, H.A., S.C. Bunting, and L.F. Neuenschwander. 1976. Effect of fire on honey mesquite. J. Range Manage. 29:467-471. 